\title{
Three Types of Skin Papillomas of Flatfishes and Their Causes
}

\author{
N. Peters and B. Watermann \\ Zoologisches Institut und Zoologisches Museum der Universität Hamburg, \\ Martin-Luther-King-Platz 3, D-2000 Hamburg 13, Federal Republic of Germany
}

\begin{abstract}
Three structurally different skin papillomas occur in flatfishes. Apparently, different causative agents are responsible. (1) Flat 'fish pox'-like tumours with a low connective tissue content occur in the Atlantic dab Limanda limanda. The high rate of occurrence in the German Bight (up to $6.6 \%$ ) might be related to the dumping of wastes consisting of sulphuric acid and titanium compounds. (2) Collagen-rich papillomas on the tip of the lower jaw appear on both Atlantic and Pacific flatfishes kept in aquaria over long periods of time. These develop as a result of mechanical stimulation of the tissue as the fishes rub against aquarium walls. (3) Complex papillomas, composed in a characteristic manner of so-called X-cells and envelope cells between them, are common in flatfishes of the Pacific region. The structure and the distribution of these complex papillomas indicate that a virus is probably involved. There also exists some relationship between tumour occurrence rate and degree of coastal water pollution.
\end{abstract}

\section{INTRODUCTION}

Many of the neoplasms observed on fishes are skin tumours, and these are predominantly epidermal papillomas (Mawdesley-Thomas, 1975). Papillomas are folded growths of the epidermis, supported and nourished by branching dermal connective tissue, the stroma. Unlike the epidermal polyp, the papilloma has an epithelium that shows strong hyperplastic thickening. So that the number of undifferentiated epidermal cells (cells of Malpighian character) is significantly increased, while highly differentiated cell types - such as mucous cells and in some cases, club and granule cells - are greatly reduced in size and number in comparison with the normal epithelium or, in some cases, are even completely eliminated.

In addition to the typical papillomas, nodular swellings frequently occur as well as flat opaque thickenings of the skin. The former usually represents a local agglomeration of dermal connective tissue, which is covered by a hyperplastic epidermis. The latter is often simply a hyperplasia of the epithelium without any contribution from the dermal connective tissue. Both growths are viewed as developmental stages of typical papillomas.

Alterations of the body surface, including tumours, are without doubt especially obvious and are therefore more frequently reported than diseases of the internal organs. It must also be remembered that, because of the intimate contact of fishes (as well as other aquatic animals) with their ambient environment, harmful materials dissolved in the water can immediately affect body surface. Our investigations support the assumption that this can be a cause for the wide distribution of skin epitheliomas in fishes.

\section{PAPILLOMAS OF THE DAB LIMANDA LIMANDA FROM THE GERMAN BIGHT}

During two field studies, carried out in the German Bight during August 1977 and April 1978, the occurrence of fish diseases was investigated (Dethlefsen, 1978). Dab, plaice (Pleuronectes platessa) and flounder (Platichthys flesus) were found with various skin lesions. All three species of flatfishes were afflicted with skin ulcers reaching several centimetres in size, with up to $7.1 \%$ of the population affected. Up to $13.9 \%$ of the samples were suffering from fin rot. Dab and flounder were observed with lymphocystis disease (up to $5.4 \%$ of the samples), and during the second collecting trip, dab (up to $6.6 \%$ of the catch) were found with flat, whitish, opaque skin thickenings a few millimetres high and up to $10 \mathrm{~mm}$ in diameter. Two or three of the various skin lesions were sometimes found together on the same individual. 


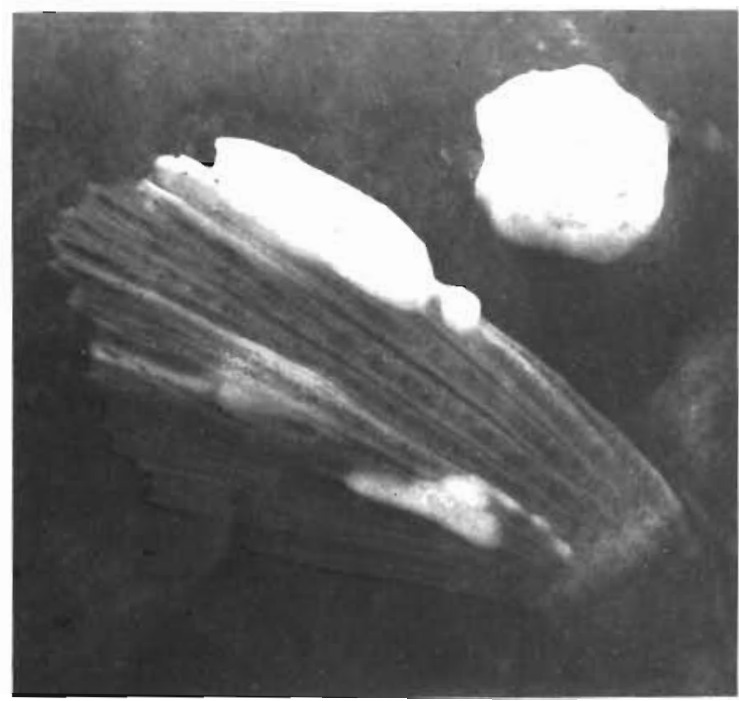

Fig. 1. Limanda limanda. Flat skin papillomas on pectoral fin (left) and body surface (right)

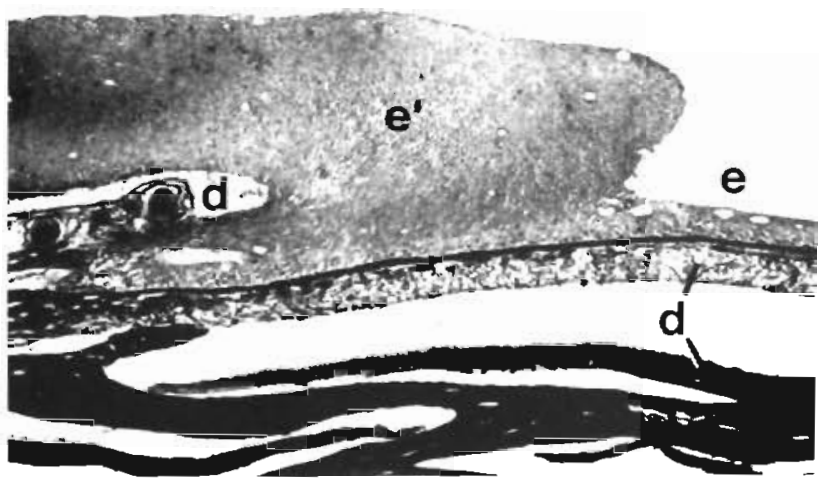

Fig. 2. Limanda limanda. LM (light microscope) section through margin of a flat skin papilloma. e: normal epidermis; e': epidermal tumour tissue; d: dermis with scales; Paraffin 7 um, H.E., x 75

Histological investigations " revealed that the opaque flecks on the dab, sometimes occurring in groups, are epidermal tumours, often with short, thick or long, finger-like extensions of the upper dermal connective tissue (stratum spongiosum) extending into the epidermal tumour tissue (Figs 1 and 2). The positions of the scales and of the other layers of the dermis are not changed. While normal epidermis is composed of only a few ( 5 to 10 at most) layers of Malpighian cells, these excrescences have 10 to 20 times as many. The basal cells on the basal lamina are usually low and seldom of

- For histologic and ultrastructure research methods see Peters et al., 1978. a high prismatic shape. The spindleshaped cells above are arranged in numerous layers, which gradually become more polyhedral in shape near the surface. The layer directly at the surface may be slightly flattened. Mostly the cells are packed tightly. Small lymphocytes are scattered chiefly in the layers near the stroma. Mucous cells are almost completely absent. According to structure, these changes in the skin can be considered epidermal hyperplasias or even papillomas if stroma folds are formed. In their flattened form, they greatly resemble those epitheliomas that have been described as 'fish pox', especially in cyprinids.

Johnstone (1925), who studied tumour formation in marine fishes near the British Isles for many years, reported this kind of skin neoplasm as cutaneous warts' on several dab. Recently, on 2 plaice out of a sample of 6000, Roberts (1976, personal communication) found tumours which exactly fit the above description. Still less frequently protrusive papillomas with papillous surfaces and branching stroma have been observed on Atlantic flatfishes: Johnstone (1925) reported the case on one dab so afflicted, and Thomas (1930) documented the condition in two sole (Solea solea).

As described by Dethlefsen (1978), only on the second field collecting trip in April 1978 were dab with these skin epitheliomas observed. The youngest tumour-bearing fish belonged to year class III. Fishermen, who were shown this skin growth, denied ever having seen it before. Considerable incidence rates were found in an area northwest of the island of Helgoland, where wastes containing titanium dioxide $\left(\mathrm{TiO}_{2}\right)$ are regulary dumped. Outside the dumping area, the tumour incidence rate in dab varies from 0 to $0.6 \%$. In the centre of the dumping area, the incidence rate was moderate $(2.9 \%)$. It was even lower in the western $(2.0 \%)$ and southern $(2.5 \%)$ parts of this area, while in the North $(4.4 \%)$ and East $(6.6 \%)$ it was highest. The distribution patterns for other skin lesions of the dab, including fin rot, lymphocystis disease, and ulcers, were found to be similar. The possiblity of a relationship between the rates of incidence and the dumping of the titanium-rich sulphuric acid wastes should be taken into account. Dethlefsen mentioned the shift of maximum rates of occurrence in relation to the drifting of the wastes in a north-easterly direction with currents prevailing in that part of the sea.

\section{PAPILLOMAS ON FLATFISHES AFTER SEVERAL YEARS CAPTTVITY IN AQUARIA}

As has already been reported (Peters et al., 1978), plaice (Pleuronectes platessa) and turbot (Scophthal- 
Fig. 3. Scophthalmus maximus. Semi-spherical skin papilloma on tip of lower jaw (arrow)

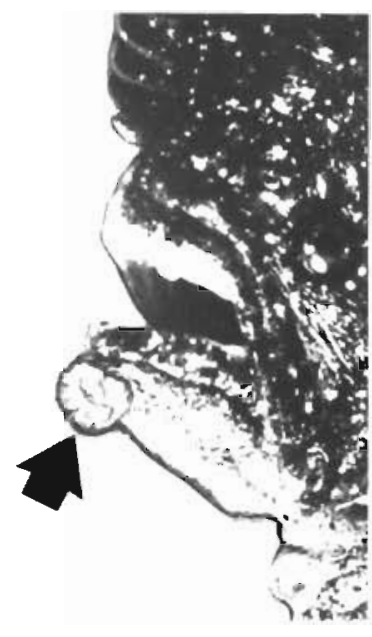

mus maximus) kept for several years in aquaria tend to develop semi-spherical tumours with wide bases, which reach a diameter of up to $2 \mathrm{~cm}$. These whitish tumours are most often found on the tip of the lower jaw (Fig. 3), but they also occur on the lower edge of the operculum and the ventral edge of the body near the anus. This kind of tumour has not been observed on any other part of the body. It has recently come to our attention that Pacific flatfishes held for years in aquaria develop these growths with a similar regularity, but we saw them only on the tip of the lower jaw."

The tumourous regions are rich in connective tissue. The smaller nodular swellings are formed chiefly by a thickening of the stratum spongiosum, but frequently a rich supply of collagen fibres running parallel to the surface gives the characteristics of the stratum compactum. These connective tissue growths are covered by a strongly hyperplastic epidermis, up to 35 cell layers thick. The macroscopic appearance of their whitish, opaque surfaces is smooth. The larger tumours are folded at the surface which corresponds to their papillomatous characteristics: a lobed, branching stroma supported by collagen is covered by strongly hyperplastic epidermal tissue. In the epidermal parts high prismatic basal cells prevail; they stand out because of their staining properties. For example, they stain darkly in toluidine blue and have an especially electron-dense cytoplasm under the electron microscope. The cells of all layers may be packed closely together and numerous mucous cells may be present, or the cells of the intermediate layers may show significant loss of intercellular contact. In the latter situation, the formation of numerous intercellular spaces

- Histological and ultrastructure investigations were conducted using 12 tissue samples taken from 3 stany flounder (Platichthys stellatus) from the Aquarium of the Nanaimo Biological Station, 2 starry flounder and 2 sand sole (Psettichthys melanostictus) from the Public Aquarium of the City of Vancouver, Canada.

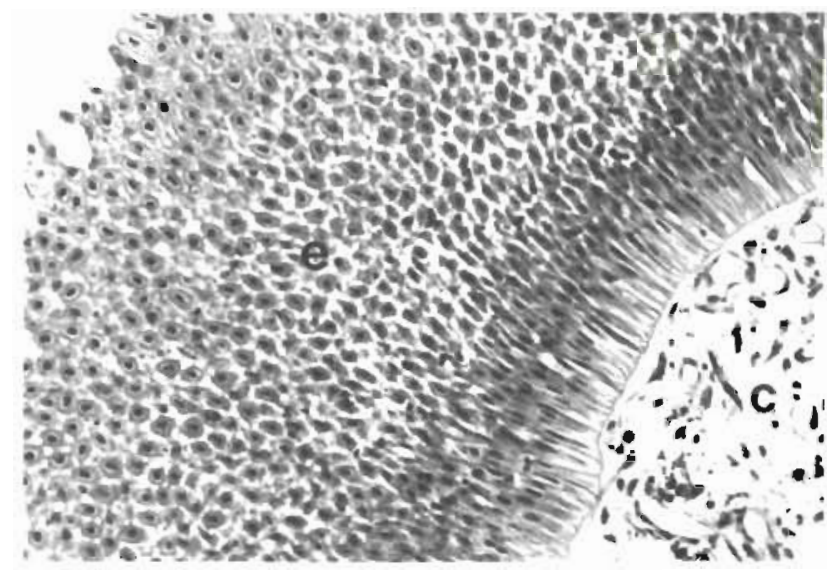

Fig. 4. Platichthys stellatus. LM Section through a semispherical skin papilloma with strongly hyperplastic epidermal tissue (e). c: connective tissue. Paraffin $7 \mu \mathrm{m}$, H.E. x 250

gives the tissue a spongy appearance (Fig. 4). Under the electron microscope it is evident that the membrane interdigitations of neighbouring cells have been mostly disengaged, maintaining contact only where processes of the cells continue to touch each other. While the tumour cells in close contact with each other resemble the Malipighian cells of normal epidermis, the cells of spongy regions are also greatly altered in that the quantity of tonofilaments in the cytoplasm is evidently reduced; the perinuclear region, in which the cell organelles (mitochondria, endoplasmic reticulum (ER), ribosomes, etc.) are concentrated, is correspondingly expanded; the number of mitochondria is about doubled, and they seem to be swollen. Mucous cells are almost completely lacking in these regions of the tumour.

These tumours apparently arise as a result of mechanical stimuli. This is evidenced by the fact that the parts of the body affected are those exposed to mechanical disturbances as the fishes contact the walls of their containers during swimming. Papillomatous tumours of jaws appear on fishes of many species after long periods of captivity. They often develop from ulcerous injuries.

Skin tumours on fishes can definitely be ascribed to abnormal mechanical stimulation in many other cases, as well. Massive skin growths are known to form at the points where fish tags have been attached to marked individuals (Amlacher, 1976). An especially evident case is that of young Pacific herring Clupea pallasii which were kept in round glass containers by Dr. J. Marliave, of Aquarium Vancouver, Canada. These fishes rubbed the glass container walls during continuous swimming in schools which always moved in the same direction. Almost all of these fish developed skin tumours on the edge of their opercula, on the left side in schools that moved chiefly clockwise, on the right 


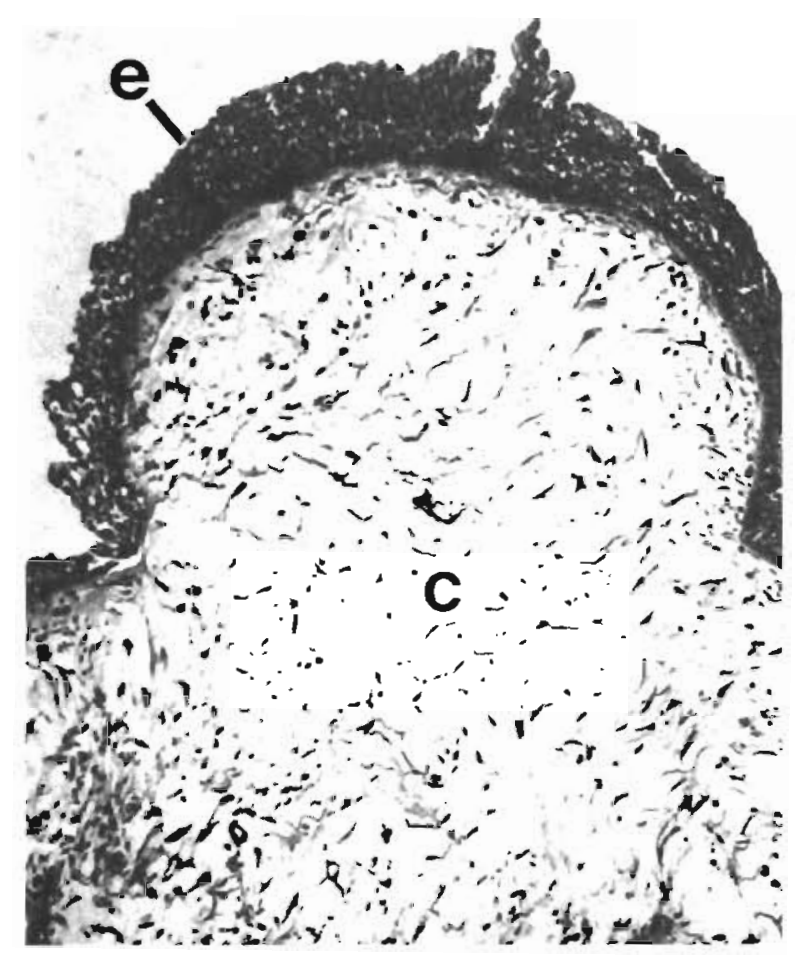

Fig. 5. Clupea pallasii. LM Section through a skin tumour on the edge of the operculum. c: connective tissue, e: epidermis. Paraffin $7 \mu \mathrm{m}, \mathrm{H}$. E. x 120

side in those generally travelling counter-clockwise. The externally smooth tumours given to us by Dr. Marliave, for histological examination, were fibroepitheliomas, outgrowths of the loose dermal connective tissue, which were covered by only moderately thickened epidermis (Fig. 5). These findings, together with the information about the structure of flatfish tumours described above, indicate that the mechanical stimulus functions especially to promote neoplastic reproduction in the dermal connective tissue.

\section{THE COMPLEX TYPE OF PAPILLOMA IN NORTH PACIFIC FLATFISHES}

Skin tumours appear with particularly high frequency in about 20 species of Pacific flatfishes from the coastal waters of North America, Japan and Korea. The infection rate reaches $58 \%$ of local populations (Stich et al., 1977). The tumours, several of which may occur on one fish, begin development a few weeks after metamorphosis as a protrusion of reddish, so-called angioepithelial nodules, up to $4 \mathrm{~mm}$ in diameter (McArn et al., 1968) (Fig. 6). These are inflammatory reactions of the dermal connective tissues with a slight thickening of the epidermis. The pigmented (upper) side of the fishes is more seriously affected than the

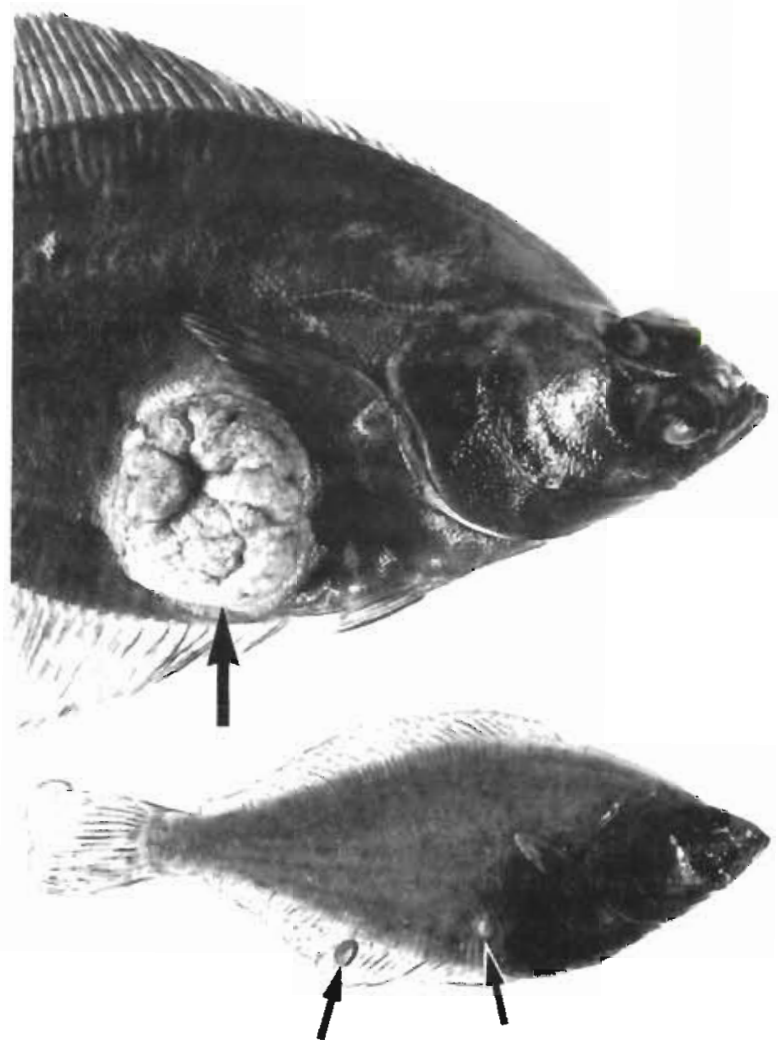

Fig. 6. Parophrys vetulus. Skin nodule and skin papilloma

unpigmented side. In the course of the following months, these nodules grow into more or less pigmented papillomas which finally reach a diameter of several centimetres and a height of up to $20 \mathrm{~mm}$. Papillomas can also form, however, without the nodular stage of development.

These papillomas are of a very complex structure (Peters et al., 1978). As the tumour increases in size, increasing numbers of the epidennal tumour cells of Malpighian character change into rounded, voluminous cells, the so-called X-cells (Brooks et al., 1969) (Fig. 7). These give the impression of being degenerative, chiefly because of the vacuolization of the mitochondria and ER. (Fig. 8). The nuclei of X-cells contain over-sized nucleoli. Numerous strongly contrasting particles of various shapes and sizes (reaching $300 \mathrm{~nm}$ in diameter) are conspicuous in the vacuolized cytoplasm. Smaller contrasting particles (up to $150 \mathrm{~nm}$ in diameter) also occur in the karyoplasm. The plasmalemma is obviously thickened. The membrane interdigitations so characteristic of the Malpighian cells,as well as the desmosomes and the tonofilaments, are lacking.

As tumour development progresses, the X-cells, 
which show absolutely no division activity, form the greatest part of the epidermal tumour tissue. But they always remain separated from each other, from the basal lamina, and from the external tumour surface by filament-containing tumour cells of Malpighian character (envelope cells). Adapting to the form of the $\mathrm{X}$ cells, the basal cells are greatly flattened and, like the intermediate cells separating the $X$-cells, they extend wing-like processes between the $X$-cells. The immediate surface is formed by one to four layers of cells of the kind and shape similar to those of the previously discussed types of papillomas.

Such $X$-cells are also more or less richly distributed in the connective tissue of the nodules, which appears inflammatory and a few of them can sometimes be found in the finely branching stroma of the papillomas; only at the edge of these tumours, against the healthy skin tissue, they are more frequent. These X-cells apparently originate from the undifferentiated mesenchymal cells, the fibroblasts (Peters et al., 1978).

Fishes from 5 to $15 \mathrm{~cm}$ in total length, belonging to the year classes 0 through II, are most often afflicted. Only occasionally are individuals in the year classes III through $V$ found to bear tumours, a fact that indicates a high mortality rate among tumourous fishes (Wellings et al., 1964). According to the fact that this condition

Fig. 7. Parophrys vetulus. LM Section through skin papilloma with X-cells $(\mathrm{x})$, tumour cells of Malpighian character with normal shape $(\mathrm{m})$, and envelope cells (arrows). s' stroma. Epon $1.0 \mu \mathrm{m}$, toluidine blue, $\times 350$

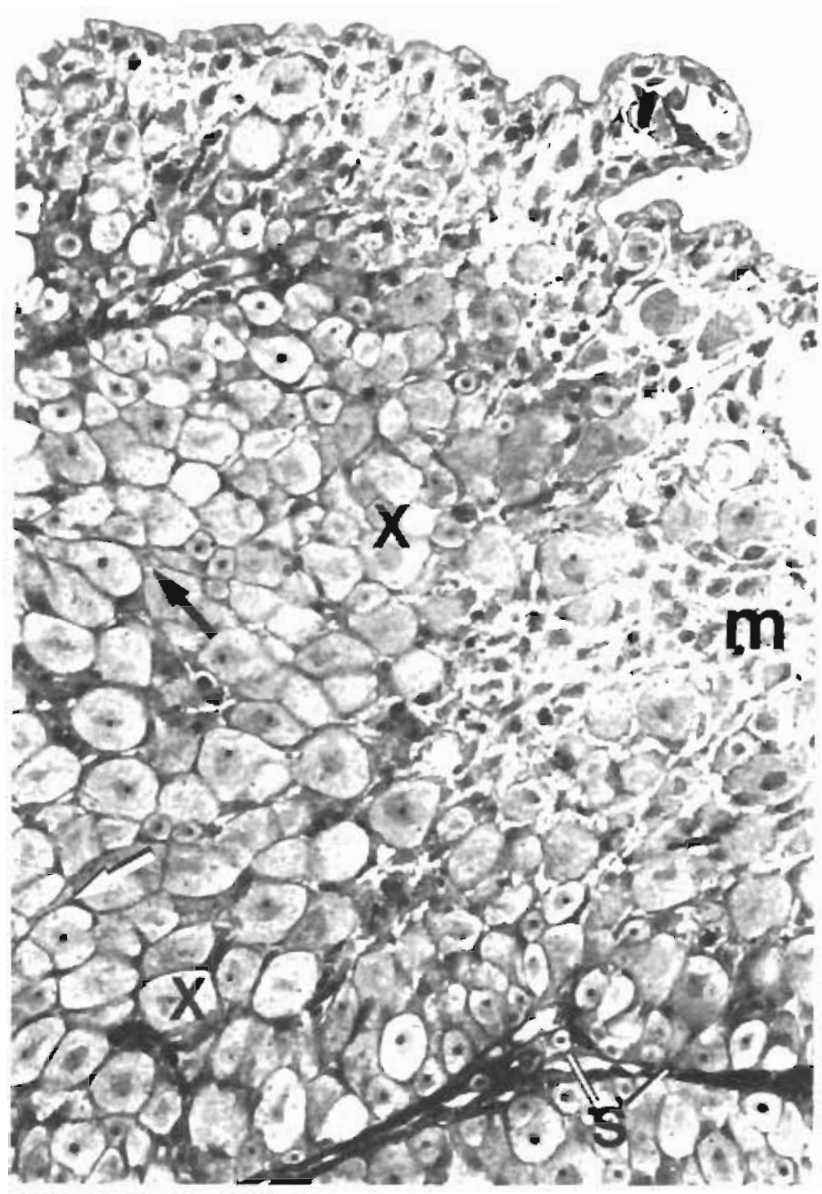

Fig. 8. Parophrys vetulus. EM (electron microscope) Section through skin papilloma with Xcell and neighbouring envelope cells. $\mathrm{n}, \mathrm{nl}, \mathrm{v}$ : nucleus, nucleolus and vacuoles of X-cell. Contrasting particles of $X$-cell arrowed. Epon $0.1 \mu \mathrm{m}, \mathrm{x} 12000$

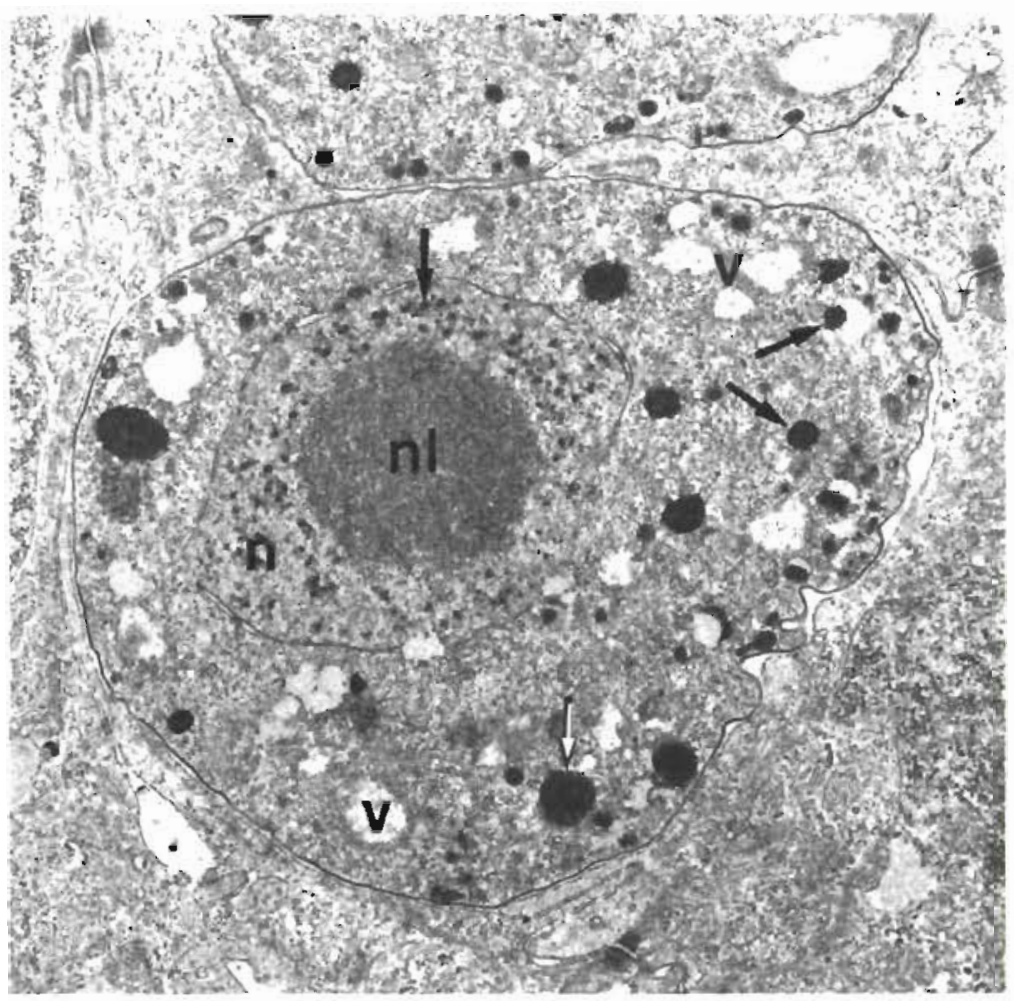


most often appears in the transition period of year class 0 and $I$ the incidence shows great seasonal variation. For comparison of the occurrence rates in fishes originating from various regions, therefore, the yearly maximum is always used.

The time of maximum occurrence in the lemon sole Parophrys vetulus of Vancouver's coastal waters is October. In the immediate region of the city, especiaily at the mouth of the Frazer River, and in the bays to the south, the maximum rate of occurrence in young fishes living near the shore ranges from 45 to almost $60 \%$ (Stich et al., 1977). The lowlands of the Frazer River mouth are heavily industrialized; they are also the site of the central sewage processing plant for the city. The region bordering the city to the north has a rocky coast indented by fjords and dotted by small islands and is thinly settled. Here the tumour occurrence rate drops sharply to almost zero. Along the coast of Vancouver Island, no tumourous fishes are found either, except in the waters off the small city of Nanaimo, where a low occurrence rate of $1.8 \%$ was found (Fig. 9).

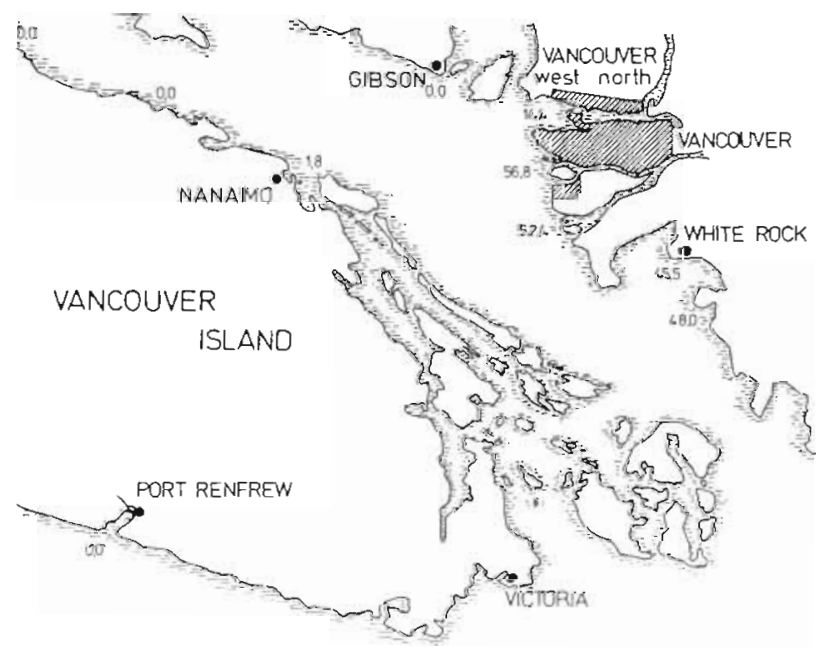

Fig. 9. Percentage of individuals with skin papillomas in populations of young English sole Parophrys vetulus in coastal areas near Vancouver, Canada (After Stich, 1977)

A comparative study of tumour occurrence along the Pacific Caost of North America from San Francisco north to Queen Charlotte Island strengthened the irnpression that the distribution of this disease is correlated with the concentrations of settlements and industrial aggregations, such as San Francisco, Eureka, Grays Harbour and most notably Seattle and Vancouver.

There are a few facts that seem to speak against this interpretation, however. For example, while both flatfish species, Parophrys vetulus and Platichthys stellatus, are highly afflicted ( $33 \%$ and $55 \%$ respectively) in the Bay of Bellingham about $50 \mathrm{~km}$ south of Vancou- ver, at the mouth of the Frazer River $P$. stellatus is only afflicted at a rate of $0.2 \%$, but $P$. vetulus at a rate of almost $60 \%$ (Stich et al., 1977). Furthermore, the sand sole (Psettichthys melanostictus) is afflicted at a rate of about $30 \%$ in the northern coastal waters off Queen Charlotte Island, which are almost free of waste contamination, while $P$. vetulus is not affected at all in these waters. At the moment these contradictions can not be satisfactorily explained either by different degrees of sensitivity to environmental influences or by different ecological demands for each of the flatfish species.

\section{DISCUSSION}

To date three kinds of flatfish skin papillomas have been observed. These can clearly be distinguished structurally as (1) flat "fish pox" - like growth with low connective tissue content, (2) prominent growths with distinct collagen-rich stroma, and (3) complex papillomas, the epidermal portion of which is composed of a characteristic arrangement of X-cells and smaller cells of Malpighian character (envelope cells) in between. The first two types correspond to the widely distributed kinds of simple fish papillomas in that they are composed purely of cells of Malpighian character.

Much evidence indicates that the structural differences of the three types depend much less on the differences in the reaction patterns of the species involved than on the kind and method in which the tumourcausing agent operates. The first type of tumour is found both in the dab and in the plaice. The second type appears in various Atlantic and Pacific species, forming in the same manner. The complex Type 3 seems to be limited to Pacific species, although a series of genera with closely related species occur in both oceans. Tumours of two kinds are sometimes observed in the same species, namely in the Atlantic plaice, which is affected by Types 1 and 2; and the Pacific sand sole and starry flounder, in which Types 2 and 3 occur. The distribution of the three papilloma types is such that different causative agents must be required.

That Type 2 papillomas of the lower jaw originate from mechanical irritation of the tissue after long periods of captivity in aquaria requires no further discussion.

Much less clear are the conditions that bring about the "fish pox'-like Type 1 epitheliomas in the dab. Dethlefsen (1978 and personal communication) reported, as mentioned earlier, that there seems to exist some relationship between its rate of occurrence and the dumping and drifting of titanium-sulphuric acid wastes and other pollutants in the German Bight. However, 80 miles northwest of the dumping area, the average rate of occurrence is still $0.6 \%$ (against $3.7 \%$ 
around the dumping area), although the highest incidence rate is offset to the northeast, apparently because of drifting. Furthermore, the rates of infection for other skin lesions of the dab (fin rot, ulcers, and lymphocystis disease) are also increased in the dumping area (not as markedly as the epitheliomas). From all these findings it can be concluded that the titanium-rich sulphuric acid wastes are possibly responsible for promoting tumour development and other skin diseases, but these substances are seemingly not the only cause.

Complex papillomas of Type 3 have been thus far observed only in Pacific waters. Besides flatfishes, these epithelial growths, consisting of X-cells and smaller cells of Malpighian character between them, are found in the goby Acanthogobius flavimanus from Japanese coastal waters, and on Pacific and Atlantic cod. On the goby these growths are also papillomas, but on the cod they occur as pseudobranchial tumours (Imai and Fujiwara, 1959; Ito et. al., 1976; Wellings et al., 1977).

It is also apparent that in the Atlantic region, lymphocystis disease is widespread among flatfishes, and also affects other fish species. This disease is a virusinduced hypertrophy of individual dermal connective tissue cells, which leads to the formation of a raspberry-shaped tumourlike swelling in the skin. In the Pacific region, lymphocystis disease seems to be very rare. Only in the Bering Sea do the distribution ranges of this disease and Type 3 complex papilloma overlap. In these waters the rock sole Lepidopsetta bilineata is afflicted with the complex type of papilloma, and the yellow-fin sole Limanda aspera by lymphocystis disease (Stich et al., 1977; Wellings et al., 1977).

The limiting of complex Type 3 papilloma to the Northern Pacific Ocean, including the Bering Sea, suggests that a non-ubiquitous infectious agent, probably a specific virus, at least plays a part in the development of this disease. The mutual isolation of Pacific flatfish papillomas and the lymphocystis disease is striking even in the Bering Sea, where no species is afflicted by both diseases. This observation leads to the supposition that both diseases are caused by interfering viruses, that is, an infection by one virus leads to a nonimmunologically determined resistance to the other. In this case, a general latent infection of Pacific flatfishes with papilloma virus must be presupposed, as well as a similar infection of Atlantic species with lymphocystis virus. The zone of conflict between the two infectious agents is the Bering Sea. The disease symptoms first appear when other pathogenic factors are present.

It has long been known that infections by oncogenic viruses often lead to tumour formation only after a simultaneous harmful environmental stimulus is applied. Experience with mammals has shown that carci- nogenic material, physical stress factors, parasitic infections, or immunosuppresiva can act as harmful stimuli (Rowson, 1975). According to Stich et al., (1977) there seems to be some relationship between coastalwater pollution and the rate of infection of the lemon sole with complex papillomas along the west coast of North America. These findings are supported by the observations of Brown et al. (1973) that all 17 fish species investigated for tumours of both internal and external organs showed a significantly higher infection rate in a heavily polluted inland water body (Fox River, Illinois) than in a less contaminated lake (Lakeof-the-Woods, Ontario). The increase in infection rate in the highly polluted Fox River ranged from $154 \%$ to $616 \%$. Among the tumours studied were also some which apparently have a virus etiology (e.g. lymphosarcoma of the pike).

In a complex reaction system composed of a tumour host, a tumour virus, and environmental factors, it is especially difficult to demonstrate directly the participation of a virus by means of reinfection experiments after isolation and purifiction of 'virus material'. Indeed, several authors have found 'virus-like' particles of various sizes and shapes in complex flatfish papillomas (Wellings et al., 1967; Stich and Acton, 1976 Peters et al., 1978). In any case, their true nature and relationship to tumour formation are not yet clarified.

Acknowledgements. We would like to thank Drs G. Bell and T. Evelyn, Biological Station Nanaimo, W Newman and J. Marliawe, Vancouver Aquarium, H. F. Stich, Cancer Research Centre, Vancouver, and A. B. Acton, Zoological Department, University of British Columbia (all British Columbia, Canada) for supplying live and preserved material. We are indebted to Dr. V. Dethlefsen, Bundesforschungsanstalt für Fischerei (Hamburg, F. R. Germany), for cooperation. We thank Mrs G. Bresching and G. Liese for distinguis hed technical assistance. This investigation was supported by grants from the Bundesministerium für Forschung und Technologie, Federal Republic of Germany, as contribution to the Canadian-German Scientific and Technical Cooperation Agreement, and by grants from the National Cancer Institute of Canada.

\section{LITERATURE CITED}

Amlacher, E. (1976). Taschenbuch der Fischkrankheiten, VEB G. Fischer Verlag, Jena.

Brooks, R. E., McArn, G. E. and Wellings, S. R. (1969). Ultrastructural observations on an unidentified cell type found in epidermal tumours of flounders. $J$. natn. Cancer Inst. 43, 97-109

Brown, E. R., Hazdra, J. J., Keith, L., Greenspan, I. and Kwapinski, J. B. G. (1973). Frequency of fish tumours found in a polluted watershed as compared to nonpolluted Canadian waters. Cancer Res., 33, 189-198.

Dethlefsen, V. (1978). Occurrence and abundance of some skeletal deformities, diseases and parasites of major fish species in dumping areas off the German Coast. Coun. Meet. int. Coun. Explor. Sea (= C.M. - I.C.E.S.), E: 8 
Johnstone, J. (1925). Malignant tumours in fishes. In Proceedings and Transactions of the Liverpool Biological Society, $39,169-200$.

Imai, T. and Fujiwara, N. (1959). An electron microscopic study of a papilloma-like hyperplastic growth in a goby, Acanthogobius flavimanus. Kyushu J. med. Sci., 10 , 135-147.

Ito, Y., Kimura, I. and Miyake, T., (1976). Histopathological and virological investigations of papillomas in soles and gobies in coastal waters of Japan. Prog. exp. Tumor Res., $20,86-93$.

Mawdesley-Thomas, L. E. (1975). Neoplasia in fish. In W. E. Ribelin and G. Migaki (Eds), The Pathology of Fishes. University of Wisconsin Press, Madison, Wisconsin. pp. 805-870.

McArn, G. E., Chuinard, R. G., Miller, B. S., Brooks, R. E. and Wellings, S. R. (1968). Pathology of skin tumours found on English sole and starry flounder from Puget Sound, Washington. J. natn. Cancer Inst., 41, 229-242.

Peters, N., Peters, G., Stich, H. F., Acton, A. B. and Bresching, G. (1978). On differences in skin tumours of Pacific and Atlantic flatfish. J. Fish Diseases, 1, 3-25.

Rowson, K. E. K. (1975). The role of viruses in cancer. In E. J.
Ambrose and F. J. C Roe (Eds), Biology of Cancer. E. Horwood, Chichester. pp. 217-251.

Stich, H. F and Acton, A. B. (1976). The possible use of fish tumors in monitoring for carcinogens in the marine environment. Prog. exp. Tumor Res., 20, 44-54.

Stich, H. F., Acton, A. B., Oishi, K., Yamazaki, F., Harada, T., Hibino, T. and Moser, H. G. (1977). Systematic collaborative studies on neoplasms in marine animals as related to the environment. Ann. N. Y. Acad. Sci., 298, 374-388.

Thomas, L. (1930). Contribution à l' étude des lesions précancéreuses chez les poissons. Les papillomes cutanés de la sole. Bull. Ass. fr. Etude Cancer, 19, 91-97.

Wellings, S. R., Chuinard, R. G., Gouiley, R. T. and Cooper, R. A. (1964). Epidermal papillomas in flathead sole, Hippoglossoides elassodon, with notes on the occurrence of similar neoplasms in other pleuronectids. J. natn. Cancer Inst., 33, 991-1004.

Wellings, S. R., Chuinard, R. G. and Cooper, R. A. (1967). Ultrastructural studies of normal skin and epidermal papillomas of the flathead sole, Hippoglossoides elassodon. Z. Zellforsch. mikrosk. Anat., 78, 370-387.

Wellings, S. R., Alpers, Ch. E., McCain, B. B. and Myers, M. S. (1977). Fish disease in the Bering Sea. Ann. N. Y. Acad. Sci., 298, 290-304.

This paper was submitted to the editor; it was accepted for printing on August 8, 1979 . 